\title{
Case Series: Familial Mediterranean fever and ankylosing spondylitis: A rare togetherness
}

\author{
Olgu serisi: Ailesel Akdeniz ateşi ve ankilozan spondilit: nadir bir birliktelik
}

\section{Rabia Aydoğan Baykara ${ }^{1}$, Nevsun Pıhtılı Taş ${ }^{2}$}

\section{Abstract}

Some seronegative spondyloarthritis cases with familial Mediterranean fever disease, ankylosing spondylitis may show clinical course. There are a limited number of publications in the literature regarding the association of sacroiliitis with Familial Mediterranean fever. In this study, four patients with clinical and radiological findings of ankylosing spondylitis were presented from 60 patients followed by familial Mediterranean fever between February 2015 and October 2016. It was aimed to emphasize the suspicion of ankylosing spondylitis in patients with familial Mediterranean fever with this case series, in case of clinical signs of gluteal pain and low back pain which can be evaluated in favor of sacroiliitis.

Keywords: Ankylosing spondylitis, Familial Mediterranean fever

\section{Öz}

Ailesel Akdeniz ateşi hastalığı ile birlikte olan bazı seronegatif spondiloartrit vakaları, ankilozan spondilit klinik seyri gösterebilir. Literatürde sakroileit ile ailesel Akdeniz ateşi birlikteliği ile ilgili sınırlı sayıda yayına rastlanmaktadır. Bu çalışmada Şubat 2015 ile Ekim 2016 dönemi arasında ailesel Akdeniz ateşi hastalığı tanısı ile takip edilen 60 hastadan, daha sonra ankilozan spondilit klinik ve radyolojik bulgularını gösteren dört olgu sunuldu. $\mathrm{Bu}$ olgu serisi ile ailesel Akdeniz ateşi tanılı hastalarda sakroileit lehine değerlendirilebilecek bel ağrısı ve gluteal ağrı klinik bulgularının olması halinde, ankilozan spondilit birlikteliğinden şüphelenilmesine vurgu yapılması amaçlandı.

Anahtar kelimeler: Ankilozan spondilit, Ailesel Akdeniz ateşi

\section{Introduction}

Familial Mediterranean fever is an autosomal recessive inherited disease which is usually characterized by recurrent and self-limiting acute fever, usually sterile peritonitis, pleuritis, monoarticular or oligoarticular arthritis with increased acute phase markers seen in Mediterranean people, especially in Turkish, Arabic and Spanish Sephardic Jews and Armenians [1]. It is caused by mutations in the MEFV gene located in the short arm of chromosome 16 .In $85 \%$ of the carrier chromosomes, four mutations related to the disease have been identified as M694V, M680I, M694I and V726A [2]. According to the latest research, the actual cause of the disease is not known even if the mutation of the Pyrin gene leads to FMF [3].

Arthritis is the second most common type of acute attack [4]. This is usually an acute spontaneous restraint monoarthritis affecting the broad joints of the lower extremities and approximately 5\% of FMF patients develop mostly arthritis of the hip or knees [5]. These features of the disease are similar to spondyloarthritis. However, available data on the role of human leukocyte antigen (HLA) B27 in the development of sacroiliitis in FMF patients should be discussed [6].

Ankylosing spondylitis (AS) is a chronic rheumatic disease of unknown etiology, and it is characterized by acute anterior uveitis, skin lesions and intestinal inflammation, as well as peripheral arthritis, peripheral oligoarthritis and enthesitis [7].Genetic factors play an important role in the pathogenesis of AS. This disease is strongly associated with HLAB27 antigen and the major histocompatibility complex region containing the HLA-B locus is the most commonly involved in genetic predisposition [8]. In addition to the association with the major histocompatibility complex region, the association of the interleukin-1 gene complex with AS has been demonstrated by several research groups.

In this study, it was aimed to emphasize the suspicion of AS in the cases with clinical symptoms such as low back pain and gluteal pain in the patients with Familial Mediterranean fever.
${ }^{1}$ Malatya Education and Research Hospital, Department of Physical Therapy and Rehabilitation, Malatya, Turkey

${ }^{2}$ University of Health Sciences, Elazig Education and Research Hospital, Department of Physical Therapy and Rehabilitation, Elazig, Turkey

Informed Consent: The author stated that the written consent was received from the patients who were presented in this study.

Hasta Onamı: Yazar çalışmada sunulan hastalardan yazılı onam alındığını ifade etmiştir.

Conflict of Interest: No conflict of interest was declared by the authors. Çıkar Çatışması: Yazarlar çıkar çatışması bildirmemișlerdir.

Financial Disclosure: The authors declared that this case has received no financial support.

Finansal Destek: Yazarlar bu olgu için finansal destek almadıklarını beyan etmişlerdir.

Geliş Tarihi / Received: 13.01.2018 Kabul Tarihi / Accepted: 21.02.2018 Yayın Tarihi / Published: 02.03.2018

Sorumlu yazar / Corresponding author Nevsun Pihtılı Tas

Adres/Address: University of Health Sciences, Elazig Education and Research Hospital, Department of Physical Therapy and Rehabilitation, Elazig, Turkey e-posta: nevsunpihtili@gmail.com

Copyright (C) ACEM 


\section{Case Series}

Patients and Methods

Between February 2015 and October 2016, patients with FMF from Malatya Education and Research Hospital Department of Physical Medicine and Rehabilitation were included in the study. The study was performed in accordance with the ethical standards of the 1964 Declaration of Helsinki and its later amendments. According to the Tel-Hashomer Criteria [9], 60 cases with a preliminary diagnosis of FMF were evaluated using hospital information system. We have identified a relationship between AS and FMF who admitted to our clinic in four of 60 patients with an incidence of $6.7 \%$. Verbal and written consent of our cases were taken from each patient.

Table 1: Clinical features of the patients.

\begin{tabular}{|c|c|c|c|c|c|c|}
\hline No & Sex & $\begin{array}{c}\text { FMF } \\
\text { diagnosi } \\
\mathrm{s} \\
\end{array}$ & $\begin{array}{c}\text { FMF } \\
\text { mutation }\end{array}$ & Sacroiliitis & $\begin{array}{l}\text { HLA } \\
\text { B27 }\end{array}$ & $\begin{array}{c}\text { Duration of } \\
\text { inflammatory } \\
\text { back pain }\end{array}$ \\
\hline 1 & male & 25 years & $\begin{array}{c}\text { M694V } \\
\text { heterozygote }\end{array}$ & + & + & 5 years \\
\hline 2 & female & 15 years & $\begin{array}{c}\mathrm{R} 202 \mathrm{Q} \\
\text { heterozygote }\end{array}$ & + & - & 10 years \\
\hline 3 & male & 2 years & E148Q & + & - & 10 years \\
\hline 4 & male & 20 years & M694V & + & + & 10 years \\
\hline
\end{tabular}

First case: 51-year-old male patient with peripheral arthritis, recurrent fever and abdominal pain episodes during his adolescence has been followed up with the diagnosis of FMF for the last 25 years. The patient described migratory gluteal pain and inflammatory back pain for the last five years. Sacroiliitis was detected with magnetic resonance imaging (Figure 1). The patient was followed up radiologically and clinically with a diagnosis of AS. The patient was HLA B 27 positive.M694V heterozygote mutation was detected in the gene analysis for FMF.

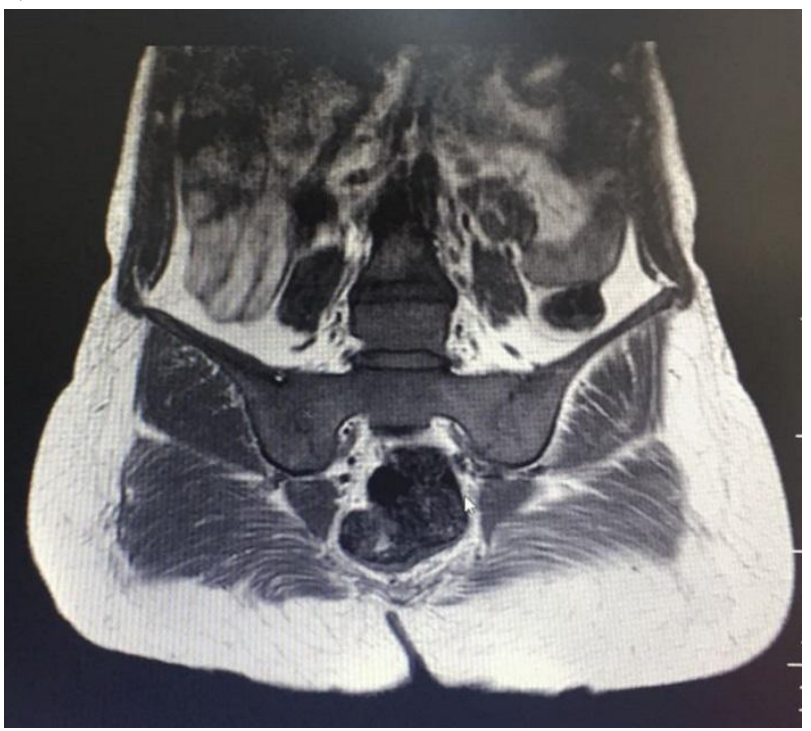

Figure 1: T1-A MRI of the sacroiliac joints showing significant narrowing of the joint spaces in both sides and hypointense changes on the iliac side of the joints.

Second Case: A 39-year-old female patient has been acquainted with FMF 15 years ago. She had (febrile fever), pain and swelling in her knee joint since her childhood. The patient has had back pain and hip pain for the last ten years. She was diagnosed as AS five years ago clinically and radiologically. The patient was HLA B 27 negative.R202Q heterozygote mutation was detected in all gene analysis of FMF.

Third Case: A 39-year-old male patient with a diagnosis of AS for the last ten years has described an abdominal pain associated with concurrent fever for the last two years. The patient was diagnosed as amyloidosis in the tests performed. FMF was considered in the patient due to positive results of the gene analysis for E148Q.
Fourth Case: A 35-year-old male patient with a diagnosis of FMF from his adulthood years was diagnosed as sacroiliitis after magnetic resonance imaging (Figure 2). He has had inflammatory back pain for the last ten years. He was HLA B27positive.

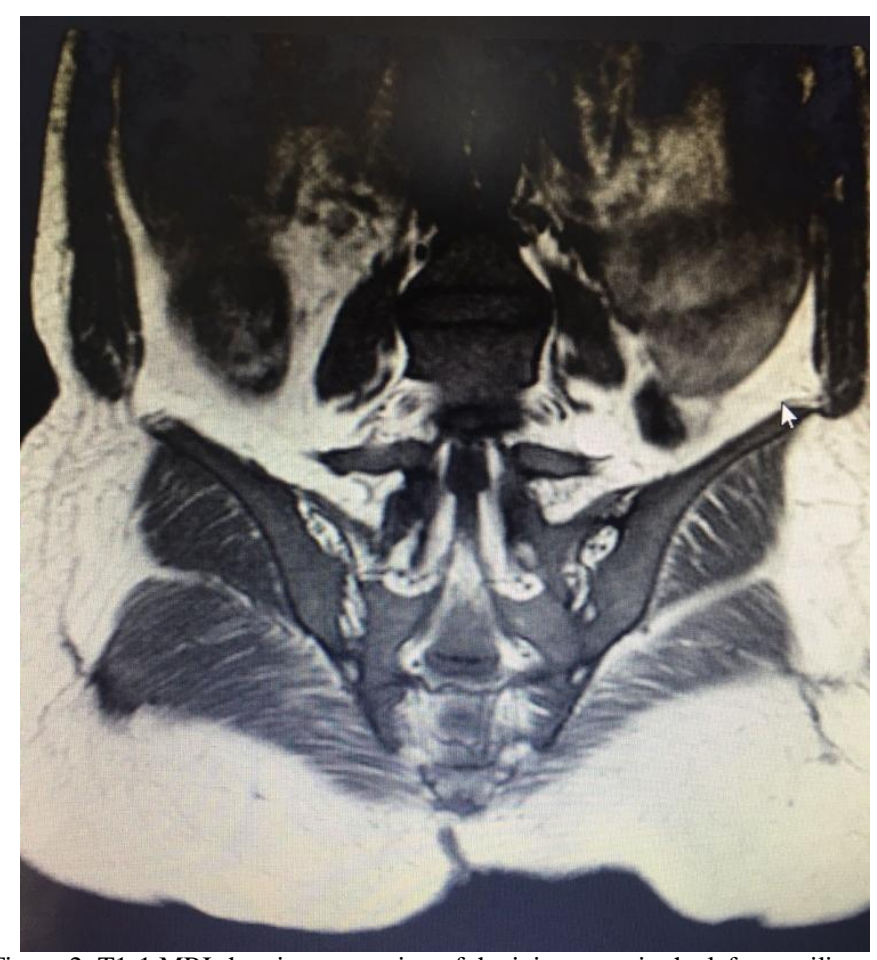

Figure 2: T1-1 MRI showing narrowing of the joint space in the left sacroiliac joint.

\section{Discussion}

The articular involvement of FMF presents as an abrupt onset of acute arthritis, accompanied by high fever, redness, warmth, tenderness, and swelling [10]. Another possible form of the joint involvement in FMF is sacroiliitis, which is the characteristic feature of seronegative spondyloarthropathy [10].

In patients with FMF, there is subclinical inflammation even in non-attack periods and ongoing inflammation due to an inflammatory cuff that can make FMF patients susceptible to other inflammatory diseases [10]. Some of seronegative spondyloarthritis cases, which present with FMF, can display a clinical scenario as in AS like our cases.

The exact relationship between FMF and AS is a challenging issue. Occurrence of FMF and AS in the same patients has been described by several authors. Majeed and Rawashdeh [12] reported only one case developed AS in a study group including 95 patients with chronic arthritis of FMF [12]. Four of our cases developed AS in a group including 60 patients with FMF.

Sacroiliitis and spondyloarthritis can be seen in patients with FMF [13]. However, the nature of this association and whether it is just a coincidence or an unexplained common etiology remains to be explored. In our four cases, sacroiliitis associated with FMF was detected.

The association of FMF and AS is frequently seen with negative HLA-B27 antigen. Langevitz et al. [14] proposed that the association of FMF and AS were seen in 11 patients in a series of 3000 patients with FMF. Further, there were nine patients who had negative HLA-B27 antigen in 11 patients with FMF and AS [14].Two of our cases HLA B 27 were positive. Kaşifoğlu et al. [15] studied the role of HLA-B27 and MEFV mutations in the development of sacroiliitis and sacroiliitis in patients with FMF. The incidence of sacroiliitis in all FMF patients was found to be $7 \%$. HLA-B27 was found to be $4.7 \%$ 
and $6.3 \%$ in patients with FMF and sacroiliitis [15]. In our patients, the incidence of sacroiliitis in 60 FMF patients was found to be $6.7 \%$.

The back pain and hip pain in our cases appeared within the several years following the diagnosis of FMF. This situation led us not to think of FMF joint involvement but also to suggest the presence of AS. Amyloidosis was detected in addition to AS in one of the cases who were positive for gene analysis.

Retrospective nature and inclusion of small number of the patients as a case series were the major limitations of the study.

In conclusion AS is a rare situation in patients with FMF. Patients usually have recurrent enthesitis and inflammatory problems with unilateral or bilateral sacroiliac joints. MEFV gene variation may be associated in the pathogenesis of FMF and AS coexistence.

\section{References}

1. Ben-Chetrit E, Levy M. Familial Mediterranean Fever. Lancet 1998; 351: 659-64.

2. Aksentiyevich I, Pras E, Gruberg L, Shen Y. Sutherland G. Refined mapping of the gene causing familial Mediterranean fever by linkage and homozygosity studies. Am Hum Genet 1993; 53: 451-61.

3. Mor A, Gal R, Livneh A. Abdominal and digestive system associations of familial Mediterranean fever. Am J Gastroenterol 2003; 98: 2594-604.

4. Tunca M, Akar S, Onen F, Özdogan H, Kasapcopur O, Yalçınkaya F, et al. Turkish FMF Working Group Familial Mediterranean Fever in Turkey (FMF): The results of a multinational country study. Medicine (Baltimore) 2005; $84: 1-11$.

5. Brik R, Shinawi M, Kasinetz L, Gershoni-Baruch R. Musculoskeletal findings of familial Mediterranean fever in children diagnosed with genetic disease. Artrit Rheum 2001; 44 : 1416-9.

6. El-Shanti H, Majeed HA, El-Khateeb M. Familial Mediterranean fever in Arabs. Lancet 2006; 367: 1016-24.

7. Onen F, Akar S, Birlik M, Sari I, Khan MA, Gurler O, et al. Prevalence of ankylosing spondyloarthritis and related spondyloarthritides in an urban area of Izmir, Turkey. J Rheumatol 2008; 35: 305-9.

8. Kausik P, El-Sobkie NI, Sheab D, Malaviya AN. Familial mediterranean fever with HLAB27 positive ankylosing spondylitis in a young Armenian man. Clin Exp Rheumatol 1999; 17: 387-8.

9. Pras M, Kastner DL. Familial Mediterranean fever. In: Klippel JH, Dieppe PA, editors. Rheumatology. 2nd ed. London: Mosby; 1997. p. 23.1-23.4

10. Ozgocmen S, Ozcakar L, Ardicoglu O, Karakoc E, Kaya A, Kiris A. Familial Mediterranean fever responds well to infliximab: single case experience. Clin Rheumatol 2006; 25: 83-7.

11. Korkmaz C, Özdoğan H, Kasapçopur O, Yazici H. Acute phase response in familial Mediterranean fever Ann Rheum Dis 2002; 61 : 79-81.

12. Majeed HA, Rawashdeh M. The clinical patterns of arthritis in children with familial Mediterranean fever. QJM 1997; 90: 37-43.

13. Avci Köksal S, Dogan N, Koçyigit H, Gürgan A. A Familial Mediterranean Fever Associated with Ankylosing Spondylitis. Rheumatism 2005; 20: 43-7.

14. Langevitz P, Livneh A, Zemer D, Shemer J, Pras M. Seronegative spondyloarthropathy in familial Mediterranean fever. Semin Arthritis Rheum 1997; 27: 67-72.

15. Kaşifoğlu T, Calişir C, Cansu DU, Korkmaz C. Role of HLA-B27 and MEFV mutations in the development of sacroiliitis frequency and sacroiliitis in familial Mediterranean fever. Clin Rheumatol 2009; 28: 41-6. 